\title{
VOLTAGE DROP CALCULATIONS \& DESIGN OF URBAN DISTRIBUTION FEEDERS
}

\author{
Ritula Thakur ${ }^{1}$, Puneet Chawla ${ }^{2}$ \\ ${ }^{1}$ Astt. Prof, National Institute of Technical Teacher's Training \& Research, Sector-26, Chandigarh \\ ${ }^{2}$ Astt Prof, Electrical Engg Dept., Ch. Devi Lal State Institute of Engg \& Tech., Panniwala Mota (Sirsa)
}

\begin{abstract}
India's power sector is characterised by inadequate and inefficient power supply. Since the country's independence, consumers are confronted with frequent power cuts, and fluctuating voltages and frequencies. In addition, system losses are high throughout India's Transmission and distribution networks. Distribution Sector requires economical system to provide electrical energy at a suitable prize and at a minimum voltage drop to reduce the voltage regulation. So, we require the economical way to provide the electrical energy by State Electricity Boards to various consumers at minimum voltage drop and reduce the regulation of voltage required for load points, tie-points to select respective kVA capacity of transformers and hence the installation of suitable capacitor banks with proper locations for improvement of power factor and harmonics. This paper suggests the different methods of reduction of distribution losses in the $11 \mathrm{kV}$ urban distribution feeder to improve the voltage profile.
\end{abstract}

Keywords: Punjab State Electricity Board, $11 \mathrm{kV}$ urban distribution feeder, ACSR conductors, voltage drop, voltage profile, coefficient of temperature rise and modulus of elasticity. $* * *$

\section{VOLTAGE DROP CALCULATION OF DISTRIBUTION FEEDERS}

Distribution Sector requires economical system to provide electrical energy at a suitable prize and at a minimum voltage drop to reduce the voltage regulation. So, we require the economical way to provide the electrical energy by State Electricity Boards to various consumers at minimum voltage drop and reduce the regulation of voltage. The invisible energy which constitutes the flow of electrons on a closed circuit to do work is called electricity.

Need of electricity is because it is a form of energy which can be converted to any other form very easily. In the past, it was thought that the electricity is a matter which flows through the circuit to do work. However, now it has been established that electricity constitutes the flow of electrons in a circuit. In this process, the work is being done. So, every matter in space is electrical because it consists of electrons and protons in it. The manifestation of a form of energy probably due to separation \& independent movement of certain parts of atoms called electrons. However, in the past, the consumption of electricity is prime motto, as it is available in lot with a capacity to do work, but as the Electrical power system consists of various elements:-

- Generating Stations

- Substations

- Transmission Systems

- Distribution Systems

- Load Points.

Role of Transmission Lines The generators, transmission and distribution system of electrical power is called as power supply system. The transmission takes power from generating stations to transmission substations through the transmission lines which are to deliver bulk power from generating stations to load centres, beyond the economical service range of regular primary distribution lines. The transmission lines can be classified into Primary and Secondary lines. Primary transmission voltages are $110 \mathrm{kV}$, $132 \mathrm{kV}, 220 \mathrm{kV}, 400 \mathrm{kV}$ and $765 \mathrm{kV}$ etc. depending upon the distance and amount of power to be transmitted, reliability. The secondary transmission voltage levels are $33 \mathrm{kV}$ or $66 \mathrm{kV}$. HVDC system is upto $\pm 600 \mathrm{kV}$.

Role of transmission lines is to transmit bulk power from generating stations to large distance loads. Thus, the transmission lines are either

(i) Aerial Lines/Overhead Lines, (ii) Underground Cables and

(ii) Compressed Gas Insulated Lines.

The vast majority of world's power is of 3- $\Phi$ aerial lines design with bare conductors \& with air as insulating medium around these conductors. For the transmission substations, power would be taken to sub-transmission substations at voltage level less than transmission voltage. This is chosen by economic consideration depend on distance and load.

Role of Distribution Lines is to deliver power from power stations or substations to load or consumers. For distribution of power, 3-phase, 4-wire AC system is usually adopted. Similarly the distribution system is either Primary or Secondary Distribution. The voltage level for primary distribution is $11 \mathrm{kV}, 6.6 \mathrm{kV}$ or $3.3 \mathrm{kV}$ etc. and the voltage level for secondary distribution is $415 \mathrm{~V}$ for large industrial 
loads or $230 \mathrm{~V}$ for small domestic loads. The size of secondary distribution is to be designed such that voltage at the last consumer premises the prescribed limit. The distribution system is further divided into

(i) Feeders, (ii) Distributors, (iii) Supply Mains

Feeders are the conductors which connect the stations to areas to be fed by these stations. Generally from the feeders, no tappings are taken to consumers. So, current loading of a feeder remains the same along its length. It is based on its current carrying capacity. The feeders are generally at voltages $11 \mathrm{kV}$ or $33 \mathrm{kV}$ whereas Distributors are conductors that are taped throughout at all points where they are laid from substation transformers to various consumers in areas to be served. The main requirement of distributors is to supply the power to consumers.

\section{POWER SECTOR IN PUNJAB}

Punjab State Electricity Board (PSEB), in its present form came into existence under Section 5 of the Electricity (Supply) Act-1948 on May 2, 1967 after the reorganization of the State. The Board was set up for generation, transmission and distribution of electricity in Punjab. The installed capacity of electricity in the State increased from 3524 MW to 1996-97 to 46409.38 MU in 2013-14 (4285.94 MU Hydel + 16306.27 MU Thermal). Thermal generation is $65 \%$ and hydro generation is $33 \%$ of the total electricity generated by the Board. The Board purchases about $25 \%$ of power available in the State. It served 52 Lakhs consumers by supplying 20192 million units of electricity in 20002001. The per capita consumption of Punjab state is 1291 $\mathrm{kWh}$ as on 31.12.2013. In 2012-13, the average cost of power supply per unit in Punjab state was 443 paise, which was the lowest in the country. The installed capacity generation in Punjab is as shown in table no. 1.1.

Table 1.1: Installed capacity generation in Punjab in Punjab

\begin{tabular}{|c|c|c|c|c|c|}
\hline $\begin{array}{l}\text { Sr. } \\
\text { No. }\end{array}$ & $\begin{array}{l}\text { Name of } \\
\text { Project }\end{array}$ & $\begin{array}{l}\text { Detail of } \\
\text { Power } \\
\text { machines } \\
\text { with } \\
\text { installed } \\
\text { capacity } \\
\text { (MW) }\end{array}$ & $\begin{array}{l}\text { Share } \\
\text { of } \\
\text { Punjab } \\
\text { (MW) }\end{array}$ & $\begin{array}{l}\text { Gener } \\
\text { ation } \\
\text { durin } \\
\text { g } \\
2013- \\
14 \\
\text { (MU) }\end{array}$ & $\begin{array}{l}\text { Gener } \\
\text { ation } \\
\text { upto } \\
31.12 \\
.2014 \\
\text { (MU) }\end{array}$ \\
\hline 1. & \multicolumn{5}{|c|}{ OWN PROJECTS } \\
\hline a) & \multicolumn{5}{|c|}{ Hydro Electric Projects } \\
\hline 1. & $\begin{array}{l}\text { Shanan } \\
\text { PH }\end{array}$ & $\begin{array}{l}4 \times 15+1 \times 50 \\
=110.00\end{array}$ & 110 & $\begin{array}{l}355.8 \\
7\end{array}$ & $\begin{array}{l}355.8 \\
7\end{array}$ \\
\hline 2. & UBDC & $\begin{array}{l}3 \times 15+3 \times 15 \\
.45=91.35\end{array}$ & 91.35 & $\begin{array}{l}361.6 \\
24\end{array}$ & $\begin{array}{l}361.6 \\
24\end{array}$ \\
\hline 3. & $\begin{array}{l}\text { Anandp } \\
\text { ur Sahib }\end{array}$ & $\begin{array}{l}4 \times 33.5=13 \\
4.00\end{array}$ & 314 & $\begin{array}{l}735.0 \\
0\end{array}$ & $\begin{array}{l}735.0 \\
0\end{array}$ \\
\hline 4. & $\begin{array}{l}\text { RSDHE } \\
\mathrm{P}\end{array}$ & $4 \times 150=600$ & 452.4 & $\begin{array}{l}1575 . \\
89\end{array}$ & $\begin{array}{l}1575 . \\
89\end{array}$ \\
\hline 5. & $\begin{array}{l}\text { Mukeria } \\
\mathrm{n}\end{array}$ & $\begin{array}{l}6 \times 15+6 \times 19 \\
.5=207.0\end{array}$ & 207 & $\begin{array}{l}1246 . \\
74\end{array}$ & $\begin{array}{l}1246 . \\
74\end{array}$ \\
\hline 6. & $\begin{array}{l}\text { Nadamp } \\
\text { ur } \\
\text { Micro }\end{array}$ & $2 \times 0.4=0.80$ & 0.8 & 10.82 & 10.82 \\
\hline
\end{tabular}

\begin{tabular}{|c|c|c|c|c|c|}
\hline 7. & $\begin{array}{l}\text { Daudhar } \\
\text { Micro }\end{array}$ & $3 \times 0.5=1.50$ & 1.5 & & \\
\hline 8. & $\begin{array}{l}\text { Rohti } \\
\text { Micro }\end{array}$ & $2 \times 0.4=0.80$ & 0.8 & & \\
\hline 9. & $\begin{array}{l}\text { Thuhi } \\
\text { Micro }\end{array}$ & $2 \times 0.4=0.80$ & 0.8 & & \\
\hline 10. & $\begin{array}{l}\text { GGSST } \\
\text { P Ropar } \\
\text { (Micro) }\end{array}$ & & 1.7 & & \\
\hline & Total & & $\begin{array}{l}1000.3 \\
5\end{array}$ & $\begin{array}{l}4285 . \\
94\end{array}$ & $\begin{array}{l}4285 . \\
94\end{array}$ \\
\hline b) & \multicolumn{5}{|c|}{ Thermal Projects } \\
\hline 1. & $\begin{array}{l}\text { GNDTP } \\
\text { Bathind } \\
\mathrm{a}\end{array}$ & $\begin{array}{l}4 \times 110=440 \\
.00\end{array}$ & 440 & $\begin{array}{l}1635 . \\
46\end{array}$ & $\begin{array}{l}2487 . \\
633\end{array}$ \\
\hline 2. & $\begin{array}{l}\text { GGSST } \\
\text { P, } \\
\text { Ropar }\end{array}$ & $\begin{array}{l}6 \times 210=126 \\
0.00\end{array}$ & 1260 & $\begin{array}{l}8805 . \\
87\end{array}$ & $\begin{array}{l}9984 . \\
65\end{array}$ \\
\hline 3. & $\begin{array}{l}\text { GHTP, } \\
\text { Lehra } \\
\text { Mohaba } \\
\text { t } \\
\text { (Bathin } \\
\text { da) }\end{array}$ & $\begin{array}{l}2 \times 210+2 \times 2 \\
50=920.00\end{array}$ & 920 & $\begin{array}{l}6664 . \\
994\end{array}$ & $\begin{array}{l}6664 . \\
994\end{array}$ \\
\hline 4. & $\begin{array}{l}\text { RSTP, } \\
\text { Jalkheri }\end{array}$ & $\begin{array}{l}1 \times 10=10.0 \\
0\end{array}$ & & & \\
\hline . & Total & & 2630 & $\begin{array}{l}1630 \\
6.27\end{array}$ & $\begin{array}{l}1630 \\
6.27\end{array}$ \\
\hline & $\begin{array}{l}\text { Total (a } \\
+\mathrm{b})\end{array}$ & & 3630 & $\begin{array}{l}2059 \\
2.21\end{array}$ & $\begin{array}{l}2059 \\
2.21\end{array}$ \\
\hline 2. & $\begin{array}{l}\text { Share } \\
\text { from } \\
\text { BBMM } \\
\text { Projects }\end{array}$ & & $\begin{array}{l}1161.0 \\
0\end{array}$ & $\begin{array}{l}4382 . \\
31\end{array}$ & $\begin{array}{l}4382 . \\
31\end{array}$ \\
\hline 3. & $\begin{array}{l}\text { Share } \\
\text { from } \\
\text { Central } \\
\text { Sector } \\
\text { Projects }\end{array}$ & & 3071 & $\begin{array}{l}2078 \\
5.71\end{array}$ & $\begin{array}{l}2078 \\
5.71\end{array}$ \\
\hline 4. & $\begin{array}{l}\text { PEDA } \\
\& \\
\text { Industri } \\
\text { al } \\
\text { Captive } \\
\text { Plants } \\
\text { installed } \\
\text { in State }\end{array}$ & & 997 & $\begin{array}{l}649.1 \\
5\end{array}$ & $\begin{array}{l}649.1 \\
5\end{array}$ \\
\hline & $\begin{array}{l}\text { Grand } \\
\text { Total } \\
(1+2+3 \\
+4)\end{array}$ & & $\begin{array}{l}8859.0 \\
0\end{array}$ & $\begin{array}{l}4640 \\
9.38\end{array}$ & $\begin{array}{l}4640 \\
9.38\end{array}$ \\
\hline
\end{tabular}

Transmission and Distribution Losses in Punjab Transmission \& distribution (T\&D) losses of the Punjab State Electricity Board (PSEB) include unavoidable inherent in the process as well as avoidable ones due to poor engineering, poor maintenance and theft. The T\&D losses in Punjab board are as under in table no. 1.2:- 
Table 1.2 Year wise distribution of T\& D losses in Punjab Electricity board

\begin{tabular}{|l|l|c|c|c|c|c|c|}
\hline Sr. No. & Description & $\mathbf{2 0 0 8 - 0 9}$ & $\mathbf{2 0 0 9 - 1 0}$ & $\mathbf{2 0 1 0 - 1 1}$ & $\mathbf{2 0 1 1 - 1 2}$ & $\mathbf{2 0 1 2 - 1 3}$ & $\mathbf{2 0 1 3 - 1 4}$ \\
\hline 1. & Energy losses (MU) & 7416.03 & 8142.85 & 6063.938 & 7235.12 & 7306.70 & 7619.96 \\
\hline 2. & \%age of T\&D losses & $19.91 \%$ & $20.12 \%$ & $18.71 \%$ & $17.42 \%$ & $16.78 \%$ & $16.95 \%$ \\
\hline
\end{tabular}

This shows that the losses in Punjab have been grossly underestimates. However, non-metering of agricultural supply makes it difficult to estimate T\&D losses accurately. The above figures of losses are calculated annually by every state electricity boards.

\section{LITREATURE SEARCH}

T\&D losses represent a significant proportion of electricity losses in both developing and developed countries. The major portion of occurrence of $T \& D$ losses is the distribution systems of the states, which makes the gap large between the demand and supply of the electricity. Electric power providers have a duty to ensure that the consumers are always supplied with the required voltage level. However, the consumers at the extreme end of the feeders have been experiencing low voltage levels, for some time now, in all the countries. This is due to, in most cases, voltage drops is a major concern in low voltage distribution systems and not very particular about voltage drop in the high voltage sides leaving it unattended.

Soloman Nunoo et al in [1] presented a paper analysing the causes and effects of voltage drop on the $11 \mathrm{KV}$ GMC subtransmission feeder in Tarkwa, Ghana. Studies showed that the voltage drop, total impedance, percentage efficiency and percentage regulation on the feeder are $944 \mathrm{~V}, 4.56 \Omega$, $91.79 \%$ and $8.94 \%$ respectively. Which all are beyond the acceptable limits. From the result, it is also realised that the causes of voltage drop on the feeder was mainly due to high impedance level as compared to the permissible value and this high impedance is caused by:-

(i) Poor jointing and terminations.

(ii) Use of undersized conductors.

(iii) Use of different types of conductor materials

(iv) Hot Spots etc.

The work concluded by proposing a number of solutions as well. In this paper, it was observed that the outage level of GMC Feeder is currently high of which stands at an average of ten times with a least duration of 10 minutes. These outages are mostly caused by:

(i) Over-grown of vegetation very close to the line, which comes in contact to the feeder in the events of strong winds.

(ii) Over-sagged conductors as a result of long spans between poles and

(iii) Obsolete headgear accessories, equipment and bent conductors.

Vujosevic, L. et al in [2] presented a paper estimating that the voltage drop in radial distribution networks can be applied for all voltage levels, therefore it was indicated in the work that in distribution system, voltage drop is the main indicator of power quality and it has a significant influence at normal working regime of electrical appliances, especially motors. This work was mainly focused on low voltage distribution system.

Konstantin et al in [3] presented a paper analyzing a power distribution line with high penetration of distributed generation and strong variation of power consumption and generation levels. In the presence of uncertainty the statistical description of the system is required to assess the risks of power outages. In order to find the probability of exceeding the constraints for voltage level and find the distribution by use of algorithm. The algorithm is based on the assumption of random but statistically distribution of loads on distribution lines. In the paper, the efficient implementation of the proposed algorithm suitable for large heterogeneous systems is a challenging task that requires a thoughtful selection of suitable the techniques of the power distribution system that would allow fast evaluation.

C.G. Carter-Brown et al in [4] presented a paper, in which a model is developed to calculate MV and LV voltage and voltage drop limits based on differential network-load combinations. The result of the model are suitable accurate for the calculation of guidelines for optimum voltage drop limits. Medium and low voltage (MV and LV) electricity distribution networks should supply customers at voltages within ranges that allow the efficient and economic operation of equipment and appliances. The permitted voltage variation is usually defined in regulations. Voltage variation is a key constraint in electricity weak networks and voltage management is applied to compensate for the voltage drop in the impedance of the distribution feeders through improving the load power factors or changing the effective ratio of the transformers and voltage regulators.

C.G. Carter-Brown et al in [5] presented a paper, which comprises of the various factors for voltage drop apportionment or voltage variation management in Eksom's distribution networks, in which voltage regulation is a term used to describe the variation of voltage.

C.G. Carter-Brown et al in [6] presented a paper, which consists of optimal voltage regulation limits and voltage drop apportionment in the distribution systems, in which the planner/ designer of a future network assumes the network will be operated in a reasonable manner (voltage control, tap settings, balanced loads and appropriate configuration of normally open points) and apportions the allowable voltage variation between the MV and LV terminals.

S.A. Qureshi et al in [7] presented a paper in his research to develop and guide lines for distribution engineers to show that by reducing the energy losses of the distribution 
systems available capacity of the system may be conserved without outing up additional capacity. A generalized computer program is used to evaluate any given HT/LT system and propose capacitor banks at different locations of feeders, different conductor sizes in different portions of system. This results in improving the stability as well as energy handling capacity of the system at minimum cost.

Amin M. et al in [8] presented a paper in his research that WAPDA power system is heavily overloaded because the system has been expanded without proper planning and increasing the required level of capital expenditure. Due to this unplanned expansion in the system, the supply conditions were sacrificed to meet the required targets. Due to this over-increasing demand for power all around, the distribution system of WAPDA remains under pressure. The methodology to increase the capacity of the system was outlined as

(i) Data collection of given power distribution system.

(ii) Analysis of power distribution system at different loads, voltage levels, conductor sizes, current levels etc.

(iii) Designing of power distribution network by simulating on computer using feeder analysis software applicable in WAPDA for calculation of parameters of system such as power factor, voltage drops, power losses, cost involved with respect to benefits gained in specific period of time etc.

(iv) Calculation of exact rating of capacitors required to improve the power factor, length of conductor to be replaced with conductor size.

(v) Energy and cost saving through the system improvement.

Beg D. et al in [9] presented a paper, which comprises of that system losses include transmission losses and distribution losses. The distribution losses make major contribution to the system losses and are about $70 \%$ of the total losses. Distribution losses being major share of the system losses needs special attention for achieving remarkable reduction in loss figure. Technical losses result from the nature and type of load, design of electrical installation/ equipment, layout of installations, poor maintenance of the system, under size and lengthy service lines, over-loading and sub-standard electrical equipments

Sarang Pande et al in [10] presented a paper, in which a method for energy losses calculation is presented. This paper demonstrates the capability of Load factor and load loss factor to calculate the power losses of the network. The data used is readily available with the engineers of power Distribution Company. The results obtained can be used for financial loss calculation and can be presented to regulate the tariff determination process. The technical losses are the losses occurred in the electrical elements during of transmission of energy from source to consumer and mainly comprises of ohmic and iron losses.
Losses in an electrical power system can be classified into two categories

(i) Current depending losses

a. Copper losses $=(\text { Current })^{2} \mathrm{x}$ resistance

(ii) Voltage depending losses

a. Iron losses of transformers

b. Dielectric losses (insulation material)

c. Losses due to corona.

\section{VOLTAGE DROP CALCULATION OF} URBAN DISTRIBUTION 11KV FAZILKA ROAD

\section{FEEDER}

The single-line diagram of the $11 \mathrm{kV}$ Fazilka Road Feeder is obtained from Punjab State Power Cooperation Ltd. is available at fig. no. 1.1 and can be hereby redrawn on ETAP software: 


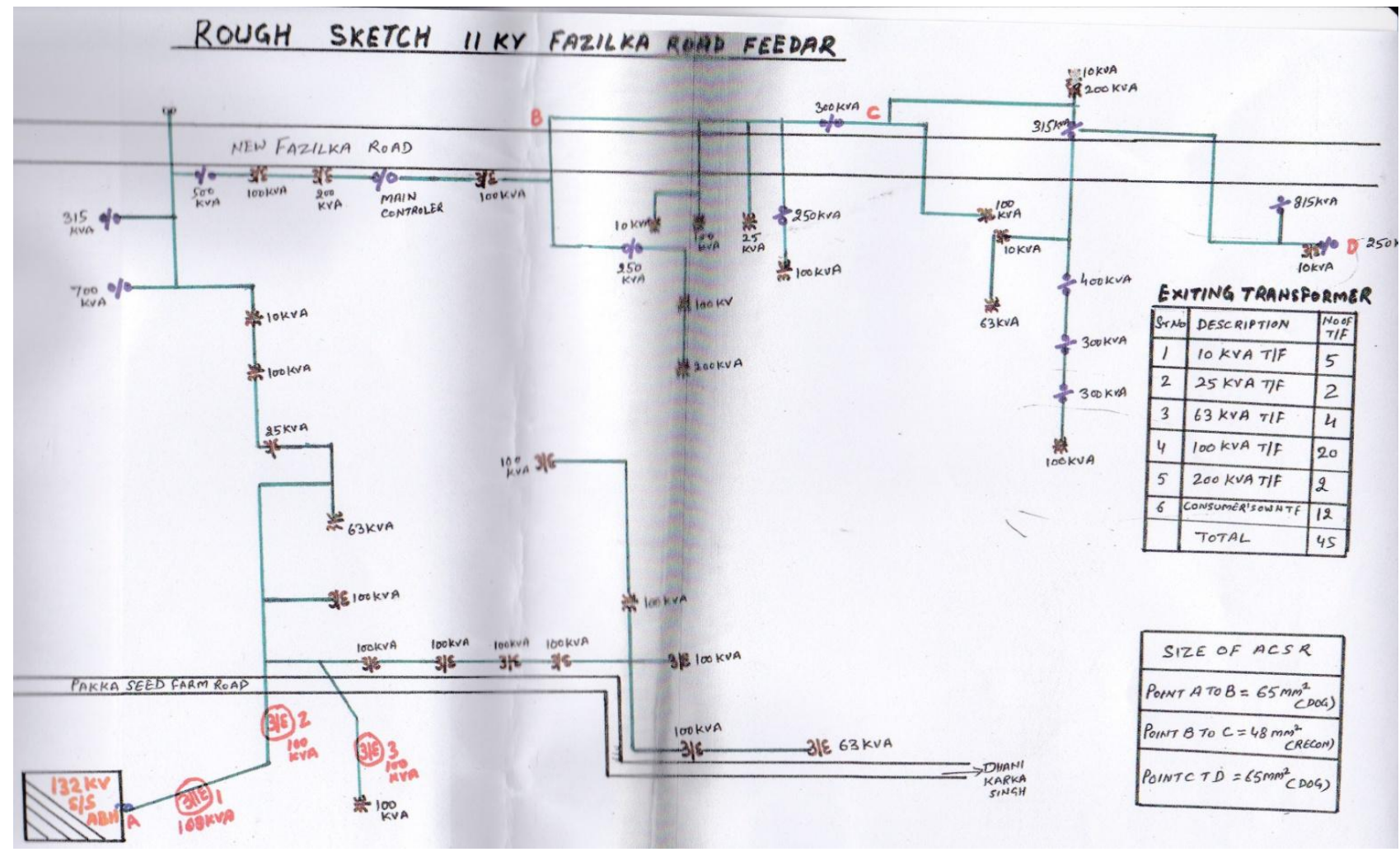

Conductor Size $=65 \mathrm{~mm}^{2}(\mathrm{DOG})$

\section{(See Annexure-I)}

Conductor Size $=48 \mathrm{~mm}^{2}(\mathrm{RACCOON})$

Resistance at $20^{\circ} \mathrm{C}=0.2745 \Omega$

Resistance at $65^{\circ} \mathrm{C}=0.3242 \Omega$

Resistance at $75^{\circ} \mathrm{C}=0.3353 \Omega$

\section{Data of Feeder}

The data obtained from State Electricity Board of Subdivision is as under as shown in table no. 1.3.

Table 1.3 Voltage drop calculation data of $11 \mathrm{kV}$ Fazilka Road Feeder

\begin{tabular}{|c|c|c|c|c|c|c|}
\hline $\begin{array}{l}\text { Sr. } \\
\text { No }\end{array}$ & $\begin{array}{l}\text { From } \\
\text { - To }\end{array}$ & $\begin{array}{l}\text { ACSR } \\
\text { size }\end{array}$ & kVA & Km & Factor & $\begin{array}{l}\text { Voltage } \\
\text { drop }\end{array}$ \\
\hline 1 & $\mathrm{AB}$ & $65 \mathrm{~mm}^{2}$ & 6322 & 0.772 & 0.0415 & 202.544 \\
\hline 2. & $\mathrm{BC}$ & $65 \mathrm{~mm}^{2}$ & 5359 & 0.160 & 0.0415 & 35.584 \\
\hline 3. & $\mathrm{CD}$ & $65 \mathrm{~mm}^{2}$ & 5259 & 0.470 & 0.0415 & 102.577 \\
\hline 4. & $\mathrm{DE}$ & $65 \mathrm{~mm}^{2}$ & 5196 & 0.464 & 0.0415 & 100.054 \\
\hline 5. & E’E1 & $65 \mathrm{~mm}^{2}$ & 5171 & 0.240 & 0.0415 & 51.503 \\
\hline 6. & E1E2 & $65 \mathrm{~mm}^{2}$ & 5071 & 0.798 & 0.0415 & 167.936 \\
\hline 7. & E2F & $65 \mathrm{~mm}^{2}$ & 5061 & 0.542 & 0.0415 & 113.837 \\
\hline 8. & FG & $65 \mathrm{~mm}^{2}$ & 4361 & 0.240 & 0.0415 & 43.436 \\
\hline 9. & $\mathrm{GH}$ & $65 \mathrm{~mm}^{2}$ & 4046 & 0.146 & 0.0415 & 24.515 \\
\hline 10. & $\mathrm{HI}$ & $65 \mathrm{~mm}^{2}$ & 3546 & 0.134 & 0.0415 & 19.719 \\
\hline 11. & IJ & $65 \mathrm{~mm}^{2}$ & 3446 & 0.145 & 0.0415 & 20.736 \\
\hline 12. & JK & $65 \mathrm{~mm}^{2}$ & 3246 & 0.052 & 0.0415 & 7.005 \\
\hline 13. & KL & $48 \mathrm{~mm}^{2}$ & 2533 & 0.740 & 0.0499 & 93.534 \\
\hline 14. & LM & $48 \mathrm{~mm}^{2}$ & 2423 & 0.100 & 0.0499 & 12.091 \\
\hline 15. & $\mathrm{MN}$ & $48 \mathrm{~mm}^{2}$ & 2398 & 0.026 & 0.0499 & 3.111 \\
\hline
\end{tabular}

\begin{tabular}{|c|c|c|c|c|c|c|}
\hline 16. & $\mathrm{NO}$ & $48 \mathrm{~mm}^{2}$ & 2048 & 0.140 & 0.0499 & 14.307 \\
\hline 17. & $\mathrm{OP}$ & $65 \mathrm{~mm}^{2}$ & 1948 & 0.654 & 0.0415 & 52.871 \\
\hline 18. & PQ & $65 \mathrm{~mm}^{2}$ & 1738 & 0.045 & 0.0415 & 3.246 \\
\hline 19. & QR & $65 \mathrm{~mm}^{2}$ & 1423 & 0.100 & 0.0415 & 5.905 \\
\hline 20. & $\mathrm{RS}$ & $65 \mathrm{~mm}^{2}$ & 1173 & 0.315 & 0.0415 & 15.334 \\
\hline 21. & ST & $65 \mathrm{~mm}^{2}$ & 250 & 0.045 & 0.0415 & 0.467 \\
\hline & & & \multicolumn{3}{|c|}{ Total Voltage drop } & 1090.312 \\
\hline
\end{tabular}

Maximum Demand $=120$ Amp.

Total circuit length of feeder $=\mathbf{6 . 3 2 8} \mathrm{km}$

Demand Factor $=\sqrt{ } 3 \times 11 \times \max$. demand

$$
\begin{aligned}
& \text { Total kVA } \\
& =\sqrt{ } 3 \times 11 \times 120 \\
& \frac{}{6322}=0.362
\end{aligned}
$$

Actual Voltage drop $=$ Total voltage drop $\mathrm{x}$ demand factor

$$
=1090.312 \times 0.362=\mathbf{3 9 4 . 3 0}
$$

$\%$ voltage drop $=$ Actual voltage drop X 100

drop $=394.30$ 11000- Actual voltage drop \% voltage

$$
X 100=\mathbf{3 . 7 2}
$$

$$
\overline{11000-394.30}
$$

On the basis of the above data, graph between the lengths of the various points on feeder versus voltage drop will be drawn in fig. no. 1.2. 


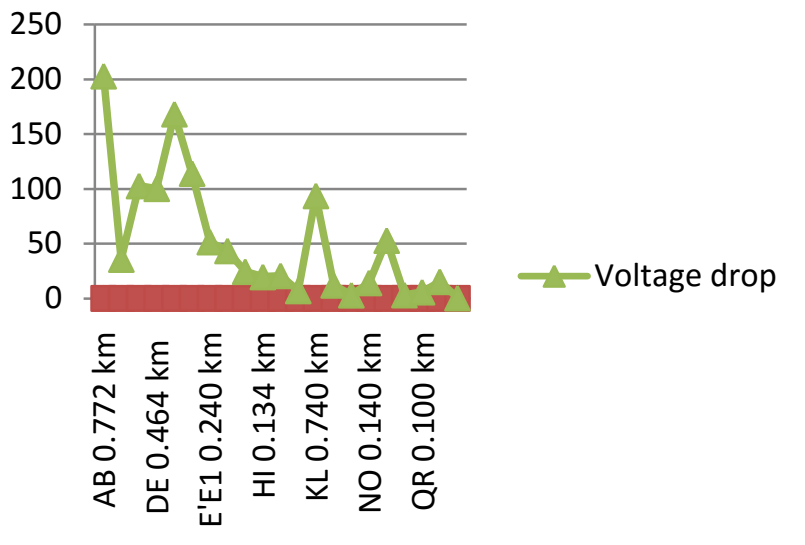

Fig 1.2 Graph between length of feeder V/s Voltage dropEstimation of Current in feeder lines

On the basis of the data of feeder, the calculation of current flowing through the feeder lines can be calculated as under in table no. 1.4.

Table 1.4 Estimation of current in feeder line

\begin{tabular}{|c|c|c|c|c|}
\hline Section & $\begin{array}{c}\text { Length } \\
\text { in km }\end{array}$ & $\begin{array}{c}\text { Voltage } \\
\text { Drop } \\
\text { (Volts) }\end{array}$ & kVA & $\begin{array}{c}\text { Current } \\
\text { in } \\
\text { feeder } \\
\text { lines }\end{array}$ \\
\hline AB & 0.772 & 202.544 & 6322 & 331.82 \\
\hline BC & 0.160 & 35.584 & 5359 & 281.27 \\
\hline CD & 0.470 & 102.577 & 5259 & 276.03 \\
\hline DE & 0.464 & 100.054 & 5196 & 272.72 \\
\hline E'E1 & 0.240 & 51.503 & 5171 & 271.41 \\
\hline E1E2 & 0.798 & 167.936 & 5071 & 266.16 \\
\hline E2F & 0.542 & 113.837 & 5061 & 265.63 \\
\hline FG & 0.240 & 43.436 & 4361 & 228.89 \\
\hline GH & 0.146 & 24.515 & 4046 & 212.36 \\
\hline HI & 0.134 & 19.719 & 3546 & 186.12 \\
\hline JJ & 0.145 & 20.736 & 3446 & 180.87 \\
\hline JK & 0.052 & 7.005 & 3246 & 170.37 \\
\hline KL & 0.740 & 93.534 & 2533 & 132.95 \\
\hline LM & 0.100 & 12.091 & 2423 & 127.17 \\
\hline MN & 0.026 & 3.111 & 2398 & 125.86 \\
\hline NO & 0.140 & 14.307 & 2048 & 107.49 \\
\hline OP & 0.654 & 52.871 & 1948 & 102.24 \\
\hline PQ & 0.045 & 3.246 & 1738 & 91.22 \\
\hline QR & 0.100 & 5.905 & 1423 & 74.69 \\
\hline RS & 0.315 & 15.334 & 1173 & 61.57 \\
\hline ST & 0.045 & 0.467 & 250 & 13.12 \\
\hline Total & $\mathbf{6 . 3 2 8 ~ k m}$ & $\mathbf{1 0 9 0 . 3 1 2}$ & & \\
\hline & & & & \\
\hline
\end{tabular}

From the above calculations, it is assumed that the current estimated on feeder line as reference current value at power factor of 0.88 (lagging).

\section{Estimation of Current at different power factor:}

On the basis of the current estimation at reference power factor of 0.88 (lagging), estimation of currents at other power factors, say 0.65 (lag) and unity power factor is also hereby calculated and is as under in table no. 1.5 on the basis of required expression.

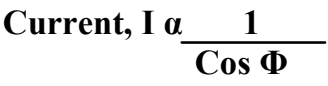

Table 1.5 Calculation of currents in feeder at various power factors

\begin{tabular}{|c|c|c|c|}
\hline Section & $\begin{array}{l}\text { Current at } \\
\text { 0.65 power } \\
\text { factor }\end{array}$ & $\begin{array}{l}\text { Current at 0.88 } \\
\text { power factor } \\
\text { (reference) }\end{array}$ & $\begin{array}{l}\text { Current } \\
\text { at unity p. } \\
\text { f. }\end{array}$ \\
\hline AB & 245.09 & 331.82 & 377.07 \\
\hline BC & 208.20 & 281.27 & 319.63 \\
\hline CD & 203.89 & 276.03 & 313.67 \\
\hline DE & 201.44 & 272.72 & 309.91 \\
\hline E'E1 & 200.47 & 271.41 & 308.42 \\
\hline E1E2 & 196.60 & 266.16 & 302.45 \\
\hline E2F & 196.20 & 265.63 & 301.85 \\
\hline FG & 169.07 & 228.89 & 260.10 \\
\hline GH & 156.86 & 212.36 & 241.32 \\
\hline HI & 137.47 & 186.12 & 211.5 \\
\hline IJ & 133.60 & 180.87 & 205.53 \\
\hline JK & 125.84 & 170.37 & 193.60 \\
\hline KL & 98.20 & 132.95 & 151.08 \\
\hline LM & 93.93 & 127.17 & 144.51 \\
\hline MN & 92.96 & 125.86 & 143.02 \\
\hline NO & 79.39 & 107.49 & 122.15 \\
\hline OP & 75.52 & 102.24 & 116.18 \\
\hline PQ & 67.38 & 91.22 & 103.66 \\
\hline QR & 55.17 & 74.69 & 84.87 \\
\hline RS & 45.48 & 61.57 & 69.96 \\
\hline ST & 9.69 & 13.12 & 14.91 \\
\hline & & & \\
\hline
\end{tabular}

\section{CALCUlation OF VOLTAGE DROP AT} VARIOUS POWER FACTORS \& TEMPERATURE

Now voltage drop can be estimated at various power factors and also at various temperatures of conductors.

\section{At power factor 0.88 (reference) and at various temperature}

Resistance at $20^{\circ} \mathrm{C}=0.2745 \Omega$

Resistance at $65^{\circ} \mathrm{C}=0.3242 \Omega$

Resistance at $75^{\circ} \mathrm{C}=0.3353 \Omega$

On the basis of the above parameters, the voltage drop calculations had been estimated in table no. 1.6 at various temperatures i.e. $20^{\circ} \mathrm{C}, 65^{\circ} \mathrm{C}$ and at $75^{\circ} \mathrm{C}$

Table 1.6 Voltage drop calculation at power factor 0.88

\begin{tabular}{|c|c|c|c|c|}
\hline $\begin{array}{c}\text { Sectio } \\
\mathbf{n}\end{array}$ & $\begin{array}{c}\text { Curren } \\
\mathbf{t} \text { at } \\
\mathbf{0 . 8 8} \mathbf{p f}\end{array}$ & $\begin{array}{c}\text { Voltage } \\
\text { drop at } \\
\mathbf{2 0}^{\mathbf{0}} \mathbf{C} \\
\text { (reference } \\
\text { ) }\end{array}$ & $\begin{array}{c}\text { Voltage } \\
\text { drop } \\
\text { at } \mathbf{6 5}^{\mathbf{0}} \mathbf{C}\end{array}$ & $\begin{array}{c}\text { Voltage } \\
\text { drop } \\
\text { at } \mathbf{7 5}^{\mathbf{0}} \mathbf{C}\end{array}$ \\
\hline $\mathrm{AB}$ & 331.82 & 91.0846 & $\begin{array}{c}107.5760 \\
4\end{array}$ & $\begin{array}{c}111.2592 \\
5\end{array}$ \\
\hline $\mathrm{BC}$ & 281.27 & 77.2086 & $\begin{array}{c}91.18773 \\
4\end{array}$ & $\begin{array}{c}94.30983 \\
1\end{array}$ \\
\hline
\end{tabular}




\begin{tabular}{|c|c|c|c|c|}
\hline $\mathrm{CD}$ & 276.03 & 75.7702 & $\begin{array}{c}89.48892 \\
6\end{array}$ & $\begin{array}{c}92.55285 \\
9\end{array}$ \\
\hline $\mathrm{DE}$ & 272.72 & 74.8616 & $\begin{array}{c}88.41582 \\
4\end{array}$ & $\begin{array}{c}91.44301 \\
6\end{array}$ \\
\hline E'E1 & 271.41 & 74.502 & $\begin{array}{c}87.99112 \\
2\end{array}$ & $\begin{array}{c}91.00377 \\
3\end{array}$ \\
\hline E1E2 & 266.16 & 73.0609 & $\begin{array}{c}86.28907 \\
2\end{array}$ & $\begin{array}{c}89.24344 \\
8\end{array}$ \\
\hline E2F & 265.63 & 72.9154 & $\begin{array}{c}86.11724 \\
6\end{array}$ & $\begin{array}{c}89.06573 \\
9\end{array}$ \\
\hline $\mathrm{FG}$ & 228.89 & 62.8303 & $\begin{array}{c}74.20613 \\
8\end{array}$ & $\begin{array}{c}76.74681 \\
7\end{array}$ \\
\hline $\mathrm{GH}$ & 212.36 & 58.2928 & $\begin{array}{c}68.84711 \\
2 \\
\end{array}$ & $\begin{array}{c}71.20430 \\
8 \\
\end{array}$ \\
\hline $\mathrm{HI}$ & 186.12 & 51.0899 & $\begin{array}{c}60.34010 \\
4\end{array}$ & $\begin{array}{c}62.40603 \\
6\end{array}$ \\
\hline IJ & 180.87 & 49.6488 & $\begin{array}{c}58.63805 \\
4\end{array}$ & $\begin{array}{c}60.64571 \\
1\end{array}$ \\
\hline $\mathrm{JK}$ & 170.37 & 46.7666 & $\begin{array}{c}55.23395 \\
4\end{array}$ & $\begin{array}{c}57.12506 \\
1\end{array}$ \\
\hline KL & 132.95 & 36.4948 & 43.10239 & $\begin{array}{c}44.57813 \\
5\end{array}$ \\
\hline LM & 127.17 & 34.9082 & $\begin{array}{c}41.22851 \\
4 \\
\end{array}$ & $\begin{array}{c}42.64010 \\
1 \\
\end{array}$ \\
\hline $\mathrm{MN}$ & 125.86 & 34.5486 & $\begin{array}{c}40.80381 \\
2\end{array}$ & $\begin{array}{c}42.20085 \\
8\end{array}$ \\
\hline $\mathrm{NO}$ & 107.49 & 29.506 & $\begin{array}{c}34.84825 \\
8 \\
\end{array}$ & $\begin{array}{c}36.04139 \\
7\end{array}$ \\
\hline OP & 102.24 & 28.0649 & $\begin{array}{c}33.14620 \\
8\end{array}$ & $\begin{array}{c}34.28107 \\
2\end{array}$ \\
\hline PQ & 91.22 & 25.0399 & $\begin{array}{c}29.57352 \\
4 \\
\end{array}$ & $\begin{array}{c}30.58606 \\
6\end{array}$ \\
\hline QR & 74.69 & 20.5024 & $\begin{array}{c}24.21449 \\
8 \\
\end{array}$ & $\begin{array}{c}25.04355 \\
7 \\
\end{array}$ \\
\hline $\mathrm{RS}$ & 61.57 & 16.901 & $\begin{array}{c}19.96099 \\
4\end{array}$ & $\begin{array}{c}20.64442 \\
1\end{array}$ \\
\hline $\mathrm{ST}$ & 13.12 & 3.60144 & 4.253504 & 4.399136 \\
\hline & & $\begin{array}{c}1037.5989 \\
4\end{array}$ & 1225.463 & 1267.420 \\
\hline
\end{tabular}

The above calculation in table no. 1.6 is hereby plotted as graph below in fig. no. 1.3.

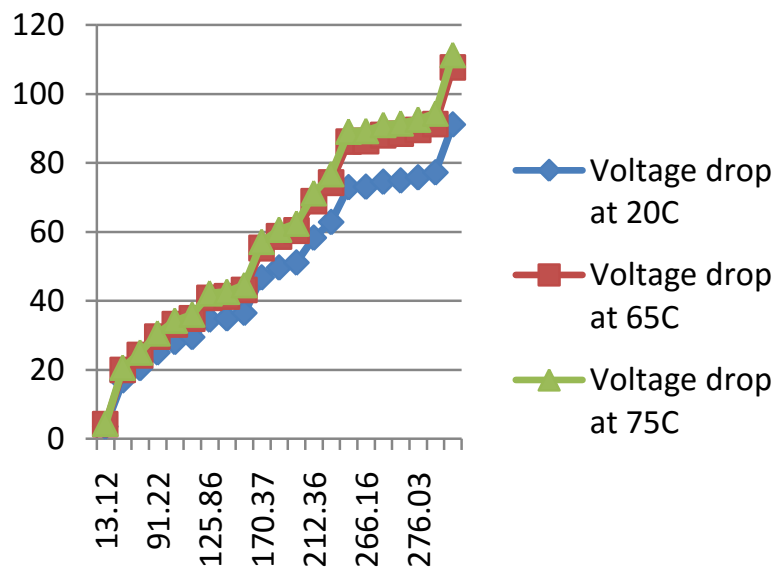

Fig 1.3 Graph between Voltage drop Vs Current at 0.88 power factor

\author{
At power factor 0.65 (lagging) and at various \\ temperature \\ Resistance at $20^{\circ} \mathrm{C}=0.2745 \Omega$ \\ Resistance at $65^{\circ} \mathrm{C}=0.3242 \Omega$ \\ Resistance at $75^{\circ} \mathrm{C}=0.3353 \Omega$
}

On the basis of the above parameters, the voltage drop calculations had been estimated in table no. 1.7 at various temperatures i.e. $20^{\circ} \mathrm{C}, 65^{\circ} \mathrm{C}$ and at $75^{\circ} \mathrm{C}$

Table 1.7 Voltage drop calculation at power factor 0.65 (lag)

\begin{tabular}{|c|c|c|c|c|}
\hline $\begin{array}{l}\text { Secti } \\
\text { on }\end{array}$ & $\begin{array}{c}\text { Current } \\
\text { at } 0.65 \mathrm{pf} \text {. } \\
\quad(\mathrm{lag})\end{array}$ & $\begin{array}{c}\text { Voltage } \\
\text { drop at } \\
20^{\circ} \mathrm{C} \\
\text { (reference) }\end{array}$ & $\begin{array}{c}\text { Voltage } \\
\text { drop } \\
\text { at } 65^{\circ} \mathrm{C}\end{array}$ & $\begin{array}{c}\text { Voltage } \\
\text { drop } \\
\text { at } 75^{\circ} \mathrm{C}\end{array}$ \\
\hline $\mathrm{AB}$ & 245.09 & 67.2772 & 79.458178 & $\begin{array}{c}82.17867 \\
7\end{array}$ \\
\hline $\mathrm{BC}$ & 208.20 & 57.1509 & 67.49844 & 69.80946 \\
\hline $\mathrm{CD}$ & 203.89 & 55.9678 & 66.101138 & $\begin{array}{c}68.36431 \\
7\end{array}$ \\
\hline $\mathrm{DE}$ & 201.44 & 55.2953 & 65.306848 & $\begin{array}{c}67.54283 \\
2\end{array}$ \\
\hline E'E1 & 200.47 & 55.029 & 64.992374 & $\begin{array}{c}67.21759 \\
1\end{array}$ \\
\hline E1E2 & 196.60 & 53.9667 & 63.73772 & 65.91998 \\
\hline E2F & 196.20 & 53.8569 & 63.60804 & 65.78586 \\
\hline FG & 169.07 & 46.4097 & 54.812494 & $\begin{array}{c}56.68917 \\
1 \\
\end{array}$ \\
\hline $\mathrm{GH}$ & 156.86 & 43.0581 & 50.854012 & $\begin{array}{c}52.59515 \\
8\end{array}$ \\
\hline $\mathrm{HI}$ & 137.47 & 37.7355 & 44.567774 & $\begin{array}{c}46.09369 \\
1\end{array}$ \\
\hline IJ & 133.60 & 36.6732 & 43.31312 & 44.79608 \\
\hline $\mathrm{JK}$ & 125.84 & 34.5431 & 40.797328 & $\begin{array}{c}42.19415 \\
2\end{array}$ \\
\hline KL & 98.20 & 26.9559 & 31.83644 & 32.92646 \\
\hline LM & 93.93 & 25.7838 & 30.452106 & $\begin{array}{c}31.49472 \\
9\end{array}$ \\
\hline $\mathrm{MN}$ & 92.96 & 25.5175 & 30.137632 & $\begin{array}{c}31.16948 \\
8\end{array}$ \\
\hline $\mathrm{NO}$ & 79.39 & 21.7926 & 25.738238 & $\begin{array}{c}26.61946 \\
7\end{array}$ \\
\hline OP & 75.52 & 20.7302 & 24.483584 & $\begin{array}{c}25.32185 \\
6 \\
\end{array}$ \\
\hline PQ & 67.38 & 18.4958 & 21.844596 & $\begin{array}{c}22.59251 \\
4\end{array}$ \\
\hline QR & 55.17 & 15.1442 & 17.886114 & $\begin{array}{c}18.49850 \\
1 \\
\end{array}$ \\
\hline $\mathrm{RS}$ & 45.48 & 12.4843 & 14.744616 & $\begin{array}{c}15.24944 \\
4 \\
\end{array}$ \\
\hline \multirow[t]{2}{*}{ ST } & 9.69 & 2.65991 & 3.141498 & 3.249057 \\
\hline & & 766.52761 & 905.31229 & 936.3084 \\
\hline
\end{tabular}

The above calculation in table no. 1.7 is hereby plotted as graph below in fig. no. 1.4 . 


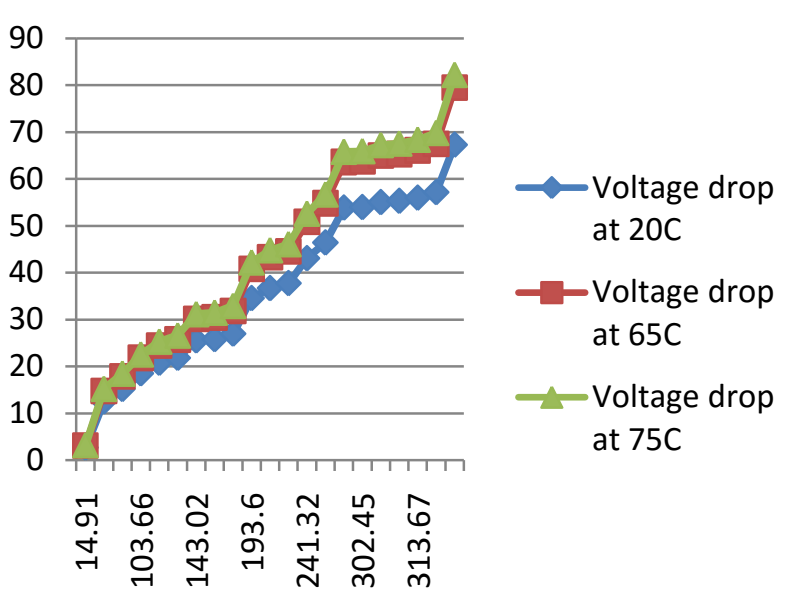

Fig 1.4 Graph between Voltage drop Vs Current at 0.65 (lag) power factor

At power factor Unity and at various temperatures

Resistance at $20^{\circ} \mathrm{C}=0.2745 \Omega$

Resistance at $65^{\circ} \mathrm{C}=0.3242 \Omega$

Resistance at $75^{\circ} \mathrm{C}=0.3353 \Omega$

On the basis of the above parameters, the voltage drop calculations had been estimated in table no. 1.8 at various temperatures i.e. $20^{\circ} \mathrm{C}, 65^{\circ} \mathrm{C}$ and at $75^{\circ} \mathrm{C}$

Table 1.8 Voltage drop calculation at Unity power factor

\begin{tabular}{|c|c|c|c|c|}
\hline $\begin{array}{c}\text { Sectio } \\
\mathbf{n}\end{array}$ & $\begin{array}{c}\text { Curren } \\
\text { t at } \\
\text { Unity } \\
\text { pf. }\end{array}$ & $\begin{array}{c}\text { Voltage } \\
\text { drop at } \\
20^{0} \mathrm{C} \\
\text { (referenc } \\
\text { e) }\end{array}$ & $\begin{array}{c}\text { Voltage } \\
\text { drop } \\
\text { at } 65^{\circ} \mathrm{C}\end{array}$ & $\begin{array}{c}\text { Voltage } \\
\text { drop } \\
\text { at } 75^{0} \mathrm{C}\end{array}$ \\
\hline $\mathrm{AB}$ & 377.07 & 67.2772 & 79.458178 & $\begin{array}{c}82.17867 \\
7\end{array}$ \\
\hline $\mathrm{BC}$ & 319.63 & 57.1509 & 67.49844 & 69.80946 \\
\hline $\mathrm{CD}$ & 313.67 & 55.9678 & 66.101138 & $\begin{array}{c}68.36431 \\
7\end{array}$ \\
\hline $\mathrm{DE}$ & 309.91 & 55.2953 & 65.306848 & $\begin{array}{c}67.54283 \\
2\end{array}$ \\
\hline E’E1 & 308.42 & 55.029 & 64.992374 & $\begin{array}{c}67.21759 \\
1\end{array}$ \\
\hline E1E2 & 302.45 & 53.9667 & 63.73772 & 65.91998 \\
\hline E2F & 301.85 & 53.8569 & 63.60804 & 65.78586 \\
\hline $\mathrm{FG}$ & 260.10 & 46.4097 & 54.812494 & $\begin{array}{c}56.68917 \\
1\end{array}$ \\
\hline $\mathrm{GH}$ & 241.32 & 43.0581 & 50.854012 & $\begin{array}{c}52.59515 \\
8 \\
\end{array}$ \\
\hline $\mathrm{HI}$ & 211.5 & 37.7355 & 44.567774 & $\begin{array}{c}46.09369 \\
1 \\
\end{array}$ \\
\hline IJ & 205.53 & 36.6732 & 43.31312 & 44.79608 \\
\hline $\mathrm{JK}$ & 193.60 & 34.5431 & 40.797328 & $\begin{array}{c}42.19415 \\
2 \\
\end{array}$ \\
\hline KL & 151.08 & 26.9559 & 31.83644 & 32.92646 \\
\hline LM & 144.51 & 25.7838 & 30.452106 & $\begin{array}{c}31.49472 \\
9 \\
\end{array}$ \\
\hline $\mathrm{MN}$ & 143.02 & 25.5175 & 30.137632 & $\begin{array}{c}31.16948 \\
8\end{array}$ \\
\hline $\mathrm{NO}$ & 122.15 & 21.7926 & 25.738238 & 26.61946 \\
\hline
\end{tabular}

\begin{tabular}{|c|c|c|c|c|}
\hline & & & & 7 \\
\hline OP & 116.18 & 20.7302 & 24.483584 & $\begin{array}{c}25.32185 \\
6\end{array}$ \\
\hline PQ & 103.66 & 18.4958 & 21.844596 & $\begin{array}{c}22.59251 \\
4\end{array}$ \\
\hline QR & 84.87 & 15.1442 & 17.886114 & $\begin{array}{c}18.49850 \\
1\end{array}$ \\
\hline RS & 69.96 & 12.4843 & 14.744616 & $\begin{array}{c}15.24944 \\
4\end{array}$ \\
\hline ST & 14.91 & 2.65991 & 3.141498 & 3.249057 \\
\hline & & $\begin{array}{c}\mathbf{7 6 6 . 5 2 7 6} \\
1\end{array}$ & $\mathbf{9 0 5 . 3 1 2 2 9}$ & $\begin{array}{c}\mathbf{9 3 6 . 3 0 8 4} \\
\mathbf{8 5}\end{array}$ \\
\hline
\end{tabular}

The above calculation in table no. 1.8 is hereby plotted as graph below in fig. no. 1.5.

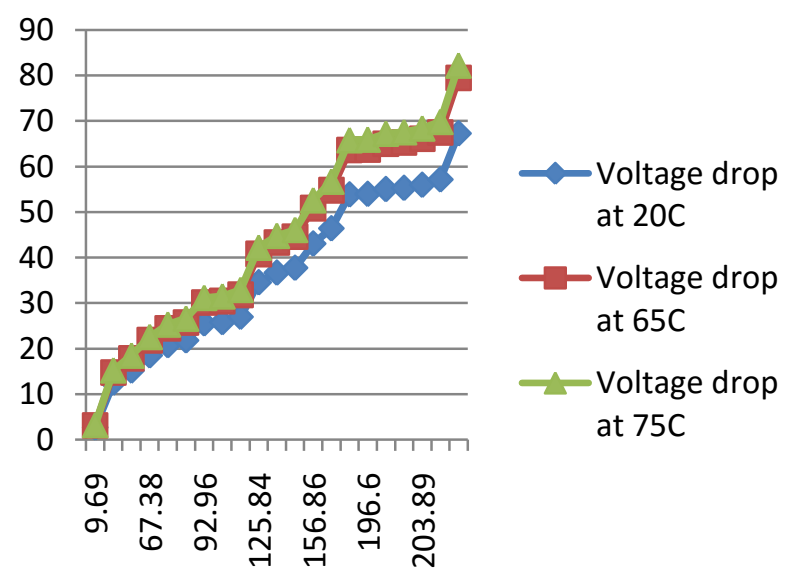

Fig 1.5 Graph between Voltage drop Vs Current at Unity power factor

\section{ALTERATION OF ACSR CONDUCTOR SIZE}

Alteration of ACSR conductor means the size of conductor used for obtaining voltage profile in the distribution feeder can be modified, so that voltage will be reached at the end consumer will be within the limits as per desired norms.

\section{Alteration of conductor with specific size}

The size of conductor used in the $11 \mathrm{kV}$ feeder, which is $65 \mathrm{~mm}^{2}$ or $48 \mathrm{~mm}^{2}$, can be modified with $80 \mathrm{~mm}^{2}$ (LEOPARD).

Existing Conductor Size of feeder $=65 \mathrm{~mm}^{2}(\mathrm{DOG})$ Proposed Conductor Size of feeder $=80 \mathrm{~mm}^{2}$ (LEOPARD) Resistance at $20^{\circ} \mathrm{C}$ of proposed conductor $=0.2193 \Omega$ Resistance at $65^{\circ} \mathrm{C}$ of proposed conductor $=0.2590 \Omega$ Resistance at $75^{\circ} \mathrm{C}$ of proposed conductor $=0.2679 \Omega$

Thus, proposed voltage drops can be estimated at various power factors and also at various temperatures of conductors.

At power factor 0.88 (reference) and at various temperature

Resistance at $20^{\circ} \mathrm{C}$ of proposed conductor $=0.2193 \Omega$

Resistance at $65^{\circ} \mathrm{C}$ of proposed conductor $=0.2590 \Omega$

Resistance at $75^{\circ} \mathrm{C}$ of proposed conductor $=0.2679 \Omega$ 
On the basis of the above parameters, the proposed voltage drop calculations had been estimated in table no. 1.9 at various temperatures i.e. $20^{\circ} \mathrm{C}, 65^{\circ} \mathrm{C}$ and at $75^{\circ} \mathrm{C}$

Table 1.9 Proposed Voltage drop calculation at power factor 0.88

\begin{tabular}{|c|c|c|c|c|}
\hline Section & $\begin{array}{c}\text { Current } \\
\text { at } \\
\mathbf{0 . 8 8 p f} .\end{array}$ & $\begin{array}{c}\text { Voltage } \\
\text { drop at } \\
\mathbf{2 0} \mathbf{C} \\
\text { (reference) }\end{array}$ & $\begin{array}{c}\text { Voltage } \\
\text { drop } \\
\text { at } \mathbf{6 5}^{\mathbf{0}} \mathbf{C}\end{array}$ & $\begin{array}{c}\text { Voltage } \\
\text { drop } \\
\text { at } \mathbf{7 5}^{\mathbf{0}} \mathbf{C}\end{array}$ \\
\hline AB & 331.82 & 72.768126 & 85.94138 & 88.89457 \\
\hline BC & 281.27 & 61.682511 & 72.84893 & 94.30981 \\
\hline CD & 276.03 & 60.533379 & 71.49177 & 94.30983 \\
\hline DE & 272.72 & 59.807496 & 70.63448 & 92.55285 \\
\hline E'E1 & 271.41 & 59.520213 & 70.29519 & 91.44301 \\
\hline E1E2 & 266.16 & 58.368888 & 68.93544 & 91.00377 \\
\hline E2F & 265.63 & 58.252659 & 68.79817 & 89.24344 \\
\hline FG & 228.89 & 50.195577 & 59.28251 & 89.06573 \\
\hline GH & 212.36 & 46.570548 & 55.00124 & 76.74681 \\
\hline HI & 186.12 & 40.816116 & 48.20508 & 71.20430 \\
\hline IJ & 180.87 & 39.664791 & 46.84533 & 62.40603 \\
\hline JK & 170.37 & 37.362141 & 44.12583 & 60.64571 \\
\hline KL & 132.95 & 29.155935 & 34.43405 & 57.12506 \\
\hline LM & 127.17 & 27.888381 & 32.93703 & 44.57813 \\
\hline MN & 125.86 & 27.601098 & 32.59774 & 42.64010 \\
\hline NO & 107.49 & 23.572557 & 27.83991 & 42.20085 \\
\hline OP & 102.24 & 22.421232 & 26.48016 & 36.04139 \\
\hline PQ & 91.22 & 20.004546 & 23.62598 & 34.28107 \\
\hline QR & 74.69 & 16.379517 & 19.34471 & 30.58606 \\
\hline RS & 61.57 & 13.502301 & 15.94663 & 25.04355 \\
\hline ST & 13.12 & 2.877216 & 3.39808 & 20.64442 \\
\hline & & $\mathbf{8 2 8 . 9 4 5 2 3}$ & $\mathbf{9 7 9 . 0 0 9 6 4}$ & $\mathbf{1 3 3 4 . 9 6}$ \\
\hline
\end{tabular}

The above calculation in table no. 1.9 is hereby plotted as graph below in fig. no. 1.6.

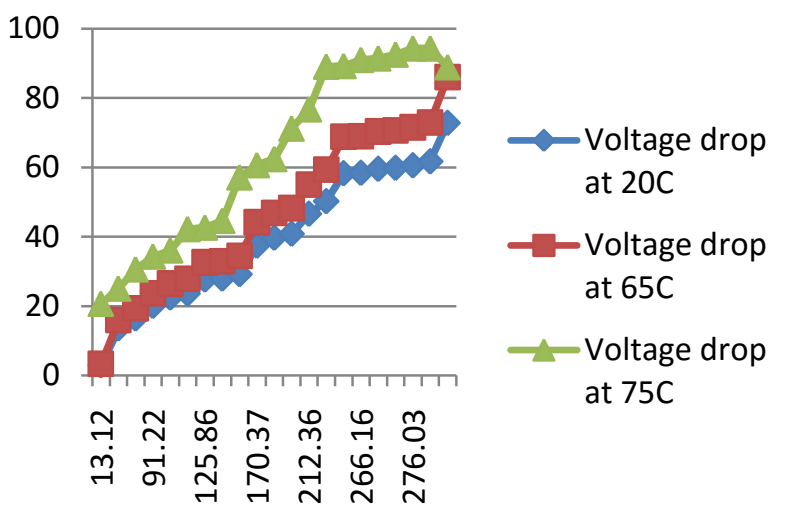

Fig 1.6 Graph between proposed Voltage drop Vs Current at 0.88 power factor

At power factor 0.65 (lagging) and at various temperature

Resistance at $20^{\circ} \mathrm{C}$ of proposed conductor $=0.2193 \Omega$

Resistance at $65^{\circ} \mathrm{C}$ of proposed conductor $=0.2590 \Omega$

Resistance at $75^{\circ} \mathrm{C}$ of proposed conductor $=0.2679 \Omega$
On the basis of the above parameters, the voltage drop calculations had been estimated in table no. 1.10 at various temperatures i.e. $20^{\circ} \mathrm{C}, 65^{\circ} \mathrm{C}$ and at $75^{\circ} \mathrm{C}$

Table 1.10 Proposed Voltage drop calculation at power factor 0.65 (lag)

\begin{tabular}{|c|c|c|c|c|}
\hline Section & $\begin{array}{c}\text { Current } \\
\text { at } \\
\mathbf{0 . 6 5} \mathbf{p f} . \\
\text { (lag) }\end{array}$ & $\begin{array}{c}\text { Voltage } \\
\text { drop at } \\
\mathbf{2 0}^{\mathbf{0}} \mathbf{C} \\
\text { (reference) }\end{array}$ & $\begin{array}{c}\text { Voltage } \\
\text { drop } \\
\text { at } \mathbf{6 5}^{\mathbf{}} \mathbf{C}\end{array}$ & $\begin{array}{c}\text { Voltage } \\
\text { drop } \\
\mathbf{a t}^{\mathbf{7}} \mathbf{C}\end{array}$ \\
\hline AB & 245.09 & 53.748237 & 63.47831 & 65.659611 \\
\hline BC & 208.20 & 45.65826 & 53.9238 & 55.77678 \\
\hline CD & 203.89 & 44.713077 & 52.80751 & 54.622131 \\
\hline DE & 201.44 & 44.175792 & 52.17296 & 53.965776 \\
\hline E'E1 & 200.47 & 43.963071 & 51.92173 & 53.705913 \\
\hline E1E2 & 196.60 & 43.11438 & 50.9194 & 52.66914 \\
\hline E2F & 196.20 & 43.02666 & 50.8158 & 52.56198 \\
\hline FG & 169.07 & 37.077051 & 43.78913 & 45.293853 \\
\hline GH & 156.86 & 34.399398 & 40.62674 & 42.022794 \\
\hline HI & 137.47 & 30.147171 & 35.60473 & 36.828213 \\
\hline IJ & 133.60 & 29.29848 & 34.6024 & 35.79144 \\
\hline JK & 125.84 & 27.596712 & 32.59256 & 33.712536 \\
\hline KL & 98.20 & 21.53526 & 25.4338 & 26.30778 \\
\hline LM & 93.93 & 20.598849 & 24.32787 & 25.163847 \\
\hline MN & 92.96 & 20.386128 & 24.07664 & 24.903984 \\
\hline NO & 79.39 & 17.410227 & 20.56201 & 21.268581 \\
\hline OP & 75.52 & 16.561536 & 19.55968 & 20.231808 \\
\hline PQ & 67.38 & 14.776434 & 17.45142 & 18.051102 \\
\hline QR & 55.17 & 12.098781 & 14.28903 & 14.780043 \\
\hline RS & 45.48 & 9.973764 & 11.77932 & 12.184092 \\
\hline ST & 9.69 & 2.125017 & 2.50971 & 2.595951 \\
\hline & & $\mathbf{6 1 2 . 3 8 4 2 9}$ & $\mathbf{7 2 3 . 2 4 4 5 5}$ & $\mathbf{7 4 8 . 0 9 7 3 6}$ \\
\hline & & & & \\
\hline
\end{tabular}

The above calculation in table no. 1.10 is hereby plotted as graph below in fig. no. 1.7.

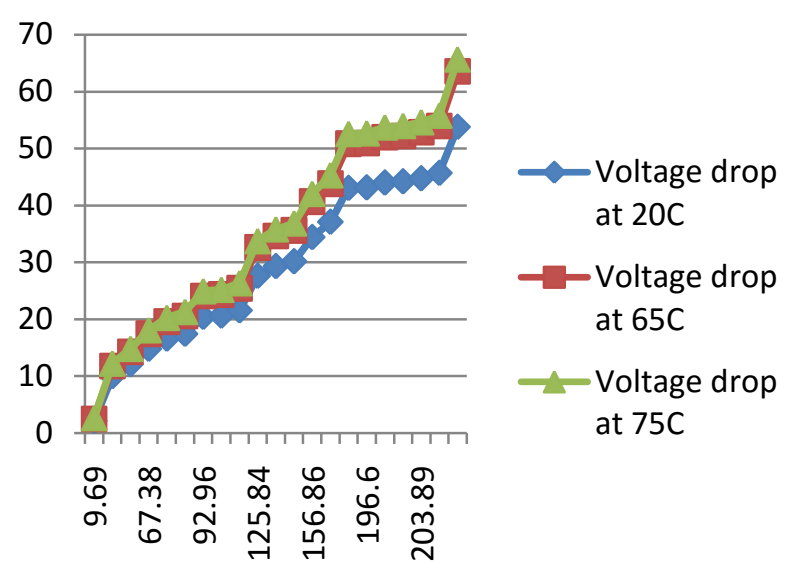

Fig 1.7 Graph between proposed Voltage drop Vs Current at 0.65 (lag) power factor

At power factor Unity and at various temperatures Resistance at $20^{\circ} \mathrm{C}$ of proposed conductor $=0.2193 \Omega$ Resistance at $65^{\circ} \mathrm{C}$ of proposed conductor $=0.2590 \Omega$ Resistance at $75^{\circ} \mathrm{C}$ of proposed conductor $=0.2679 \Omega$ 
On the basis of the above parameters, the voltage drop calculations had been estimated in table no. 1.11 at various temperatures i.e. $20^{\circ} \mathrm{C}, 65^{\circ} \mathrm{C}$ and at $75^{\circ} \mathrm{C}$

Table 1.11 Proposed Voltage drop calculation at Unity power factor

\begin{tabular}{|c|c|c|c|c|}
\hline Section & $\begin{array}{c}\text { Current } \\
\text { at Unity } \\
\text { pf. }\end{array}$ & $\begin{array}{c}\text { Voltage } \\
\text { drop at } \\
\mathbf{2 0}^{\mathbf{0}} \mathbf{C} \\
\text { (reference) }\end{array}$ & $\begin{array}{c}\text { Voltage } \\
\text { drop } \\
\text { at } \mathbf{6 5}^{\mathbf{0}} \mathbf{C}\end{array}$ & $\begin{array}{c}\text { Voltage } \\
\text { drop } \\
\text { at } \mathbf{7 5}^{\mathbf{0}} \mathbf{C}\end{array}$ \\
\hline AB & 377.07 & 82.691451 & 97.66113 & 101.01705 \\
\hline BC & 319.63 & 70.094859 & 82.78417 & 85.628877 \\
\hline CD & 313.67 & 68.787831 & 81.24053 & 84.032193 \\
\hline DE & 309.91 & 67.963263 & 80.26669 & 83.024889 \\
\hline E'E1 & 308.42 & 67.636506 & 79.88078 & 82.625718 \\
\hline E1E2 & 302.45 & 66.327285 & 78.33455 & 81.026355 \\
\hline E2F & 301.85 & 66.195705 & 78.17915 & 80.865615 \\
\hline FG & 260.10 & 57.03993 & 67.3659 & 69.68079 \\
\hline GH & 241.32 & 52.921476 & 62.50188 & 64.649628 \\
\hline HI & 211.5 & 46.38195 & 54.7785 & 56.66085 \\
\hline IJ & 205.53 & 45.072729 & 53.23227 & 55.061487 \\
\hline JK & 193.60 & 42.45648 & 50.1424 & 51.86544 \\
\hline KL & 151.08 & 33.131844 & 39.12972 & 40.474332 \\
\hline LM & 144.51 & 31.691043 & 37.42809 & 38.714229 \\
\hline MN & 143.02 & 31.364286 & 37.04218 & 38.315058 \\
\hline NO & 122.15 & 26.787495 & 31.63685 & 32.723985 \\
\hline OP & 116.18 & 25.478274 & 30.09062 & 31.124622 \\
\hline PQ & 103.66 & 22.732638 & 26.84794 & 27.770514 \\
\hline QR & 84.87 & 18.611991 & 21.98133 & 22.736673 \\
\hline RS & 69.96 & 15.342228 & 18.11964 & 18.742284 \\
\hline ST & 14.91 & 3.269763 & 3.86169 & 3.994389 \\
\hline & & $\mathbf{9 4 1 . 9 7 9 0 3}$ & $\mathbf{1 1 1 2 . 5 0 6}$ & $\mathbf{1 1 5 0 . 7 3 5}$ \\
\hline & & & & \\
\hline
\end{tabular}

The above calculation in table no. 1.11 is hereby plotted as graph below in fig. no. 1.8 .

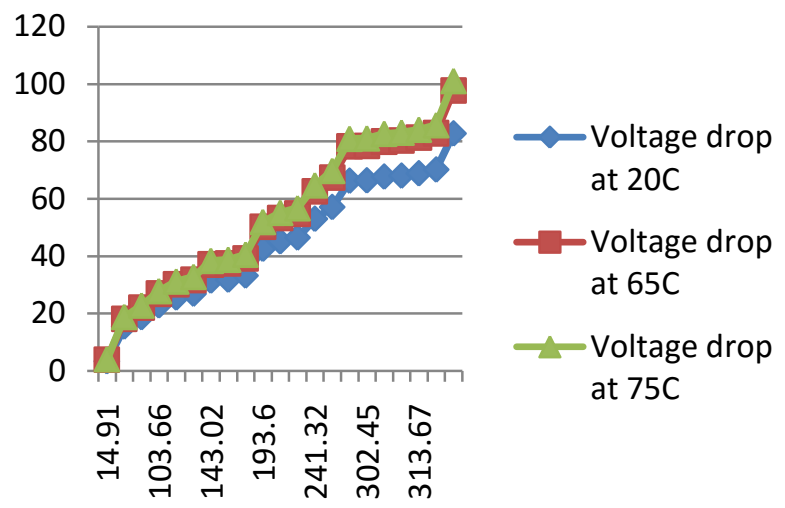

Fig 1.8 Graph between proposed Voltage drop Vs Current at Unity power factor

\section{CONCLUSION}

Hence, it has been observed that the existing feeder is to be operated on 0.88 power factor at a temperature range of conductor at $20^{\circ} \mathrm{C}$, however it is come to notice while analysing that the conductor size can be augmentated with $65 \mathrm{~mm}^{2}$ (DOG) and $48 \mathrm{~mm}^{2}$ (RACCOON) to the use of
$80 \mathrm{~mm}^{2}$ (LEOPARD) and $50 \mathrm{~mm}^{2}$ (OTTER) for reduction of voltage drop in feeder, due to its better current carrying capacity of $375 \mathrm{~A}$ in comparison of $324 \mathrm{~A}$ of $65 \mathrm{~mm}^{2}$ conductor and same linear coefficient of temperature rise and modulus of elasticity, as observed from the diagram obtained after analysis.

But the weight of $80 \mathrm{~mm}^{2}$ conductor is $27.9 \mathrm{~mm}^{2}$ increased, which can be supported by the existing structures installed in the feeder area.

Location, proper placement and sizing of the capacitor banks for improving the power factors and harmonics in the $11 \mathrm{kV}$ urban distribution feeders of the Subdivision can be investigated for improvement in system performance. Effects of High Voltage Distribution systems (HVDS) on the $11 \mathrm{kV}$ distribution feeders will be considered for better solutions. Effects of under sizing of the conductors was checked and recommendation for proper sizing of the conductors is hereby recommended for operation. Estimation of Hot spots will be checked and thus the performance will be enhanced and estimation of poor jointing and terminations will be another methodology for proper fault maintenance to be carried out.

\section{REFERENCES}

[1] Soloman Nunoo, Joesph C. Attachie and Franklin N. Duah, "An Investigation into the Causes and Effects of Voltage drops on $11 \mathrm{KV}$ Feeder", Canadian Journal of Electrical and Electronics Engineering, Vol. 3, January, 2012.

[2] Vujosevic, L. Spahic E. and Rakocevic D., "One Method for the Estimation of voltage drop in Distribution System", http://www.docstoc.com/document/ education, March, 2011.

[3] Konstantin S. Turitsyn, "Statistics of voltage drop in radial distribution circuits: a dynamic programming approach", arXiv,:1006.0158v, June, 2010.

[4] C.G. Carter-Brown and C.T. Gaunt, "Model for the apportionment of the total voltage drop in Combined Medium and Low Voltage Distribution Feeders", Journal of South African Institute of Electrical Engineers, Vol. 97(1), March, 2006.

[5] C.G. Carter-Brown, "Voltage drop apportionment in Eskom's distribution networks", Masters dissertation, University of Cape Town South Africa, pp. 28-33, 50,52,55,60, 2002.

[6] C.G. Carter-Brown, "Optimal voltage regulation limits and voltage drop apportionment in distribution systems", $11^{\text {th }}$ Southern African Universities Power Engineering Conference (SAUPEC, 2002) pp. 318322, Jan/Feb., 2002.

[7] S.A. Qureshi and F. Mahmood, "Evaluation by implementation of Distribution System Planning for Energy Loss Reduction", Pal. J. Engg. \& Appl. Sci., Vol. 4, pp. 43-45, January, 2009.

[8] M. Amin., M.Sc. Thesis, Electrical Engineering Department, UET, Lahore, Pakistan, 2006. 
[9] D. Beg. and J. R. Armstrong, "Estimation of Technical Losses for Distribution system Planning", IEEE Power Engineering Journal, Vol. 3, pp. 337343, 1989.

[10] Sarang Pande and Prof. J. G. Ghodekar, "Computation of Technical Power Loss of Feeders and Transformers in Distribution System using Load Factor and Load Loss Factor", International Journal of Multidisciplinary Sciences and Engineering, Vol 3. No. 6, June, 2012.

Annexure-I

Table: Aluminium Conductor Steel Reinforced [Based on IS: 398(1961)]

\begin{tabular}{|c|c|c|c|c|c|c|c|c|c|c|c|c|c|c|c|c|}
\hline \multicolumn{3}{|c|}{ Conductor } & \multicolumn{2}{|c|}{$\begin{array}{l}\text { Electrical } \\
\text { properties }\end{array}$} & \multicolumn{4}{|c|}{$\begin{array}{c}\text { Stranding and Wire } \\
\text { diameter }\end{array}$} & \multicolumn{8}{|c|}{ Mechanical Properties } \\
\hline 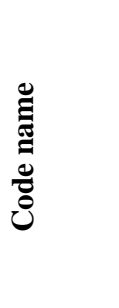 & 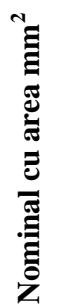 & 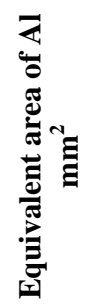 & 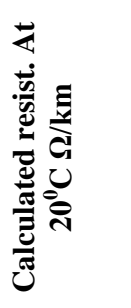 & 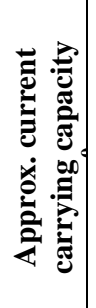 & $\frac{\dot{2}}{\dot{z}}$ & 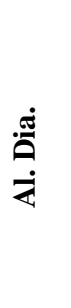 & $\frac{\dot{\theta}}{\stackrel{\Xi}{\tilde{D}}}$ & 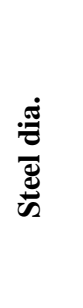 & 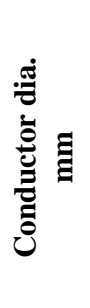 & 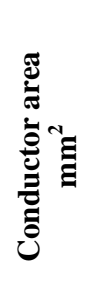 & $\frac{\vec{\theta}}{\stackrel{5}{0}}$ & $\begin{array}{l}\dot{z} \\
\dot{3} \\
\dot{3}\end{array}$ & $\begin{array}{l}\bar{\Xi} \\
\text { कू } \\
\dot{0} \\
\dot{0}\end{array}$ & 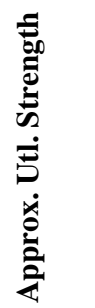 & 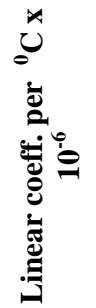 & 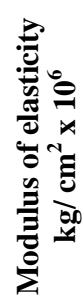 \\
\hline 1 & 2 & 3 & 4 & 5 & 6 & 7 & 8 & 9 & 10 & 11 & 12 & 13 & 14 & 15 & 16 & 17 \\
\hline Mole & 6.5 & 10.47 & 2.71800 & - & 6 & 1.50 & 1 & 1.50 & 4.50 & 12.37 & 43 & 29 & 14 & 408 & 18.99 & 0.809 \\
\hline Squirrel & 13 & 20.71 & 1.37400 & 115 & 6 & 2.11 & 1 & 2.11 & 6.33 & 24.48 & 85 & 58 & 27 & 771 & 18.99 & 0.809 \\
\hline Gopher & 16 & 25.91 & 1.09800 & 133 & 6 & 2.36 & 1 & 2.36 & 7.08 & 30.62 & 106 & 72 & 34 & 952 & 18.99 & 0.809 \\
\hline Weasel & 20 & 31.21 & 0.91160 & 150 & 6 & 2.59 & 1 & 2.59 & 7.77 & 36.88 & 128 & 87 & 41 & 1136 & 18.99 & 0.809 \\
\hline Ferret & 25 & 41.87 & 0.67950 & 181 & 6 & 3.00 & 1 & 3.00 & 9.00 & 49.48 & 171 & 116 & 55 & 1503 & 18.99 & 0.809 \\
\hline Rabbit & 30 & 52.21 & $0.544+0$ & 208 & 6 & 3.35 & 1 & 3.35 & 10.05 & 61.71 & 214 & 145 & 69 & 1860 & 18.99 & 0.809 \\
\hline Mink & 40 & 62.32 & 0.45650 & 234 & 6 & 3.66 & 1 & 3.66 & 10.98 & 73.65 & 255 & 172 & 82 & 2208 & 18.99 & 0.809 \\
\hline Horse & 42 & 71.58 & 0.39770 & - & 12 & 2.79 & 7 & 2.79 & 13.95 & 116.20 & 542 & 204 & 338 & 6108 & 15.30 & 1.070 \\
\hline Beaver & 45 & 74.07 & 0.38410 & 261 & 6 & 3.99 & 1 & 3.99 & 11.97 & 87.53 & 303 & 205 & 98 & 2613 & 18.99 & 0.809 \\
\hline Raccoon & 48 & & 0.3646 & 270 & 6 & 4.09 & 1 & & & & 218 & 215 & & 2746 & 18.99 & 0.809 \\
\hline Otter & 50 & 82.85 & 0.34340 & 281 & 6 & 4.22 & 1 & 4.22 & 12.66 & 97.91 & 339 & 230 & 109 & 2923 & 18.99 & 0.809 \\
\hline Cat & 55 & 94.21 & 0.30200 & 305 & 6 & 4.50 & 1 & 4.50 & 13.50 & 111.30 & 385 & 261 & 125 & 3324 & 18.99 & 0.809 \\
\hline Dog & 65 & 103.60 & 0.27450 & 324 & 6 & 4.72 & 7 & 1.57 & 14.16 & 118.50 & 394 & 288 & 109 & 2399 & 19.53 & 0.735 \\
\hline Leopard & 80 & 29.70 & 0.21930 & 375 & 6 & 5.28 & 7 & 1.76 & 15.84 & 148.40 & 493 & 360 & 133 & 4137 & 19.53 & 0.735 \\
\hline Coyote & 80 & 28.50 & 0.22140 & 375 & 26 & 2.51 & 7 & 1.90 & 15.86 & 151.60 & 521 & 365 & 15 & 4638 & 18.99 & 0.773 \\
\hline Tiger & 80 & 128.10 & 0.22210 & 382 & 30 & 2.3 & 7 & 2.36 & 16.52 & 161.80 & 604 & 363 & 24 & 5758 & 17.73 & 0.787 \\
\hline Wolf & 95 & 154.30 & 0.18440 & 430 & 30 & 2.59 & 7 & 2.59 & 1.13 & 195.00 & 727 & 436 & 291 & 6880 & 17.73 & 0.787 \\
\hline Lynx & 110 & 179.00 & 0.15890 & 475 & 30 & 2.79 & 7 & 2.79 & 19.53 & 226.20 & 844 & 506 & 338 & 7950 & 17.73 & 0.787 \\
\hline Panther & 130 & 207.00 & 0.13750 & 520 & 30 & 3.00 & 7 & 3.00 & 21.00 & 261.60 & 976 & 586 & 390 & 9127 & 17.73 & 0.787 \\
\hline Lion & 140 & 232.30 & 0.12230 & 555 & 30 & 3.18 & 7 & 3.18 & 22.26 & 293.90 & 1097 & 659 & 438 & 10210 & 17.73 & 0.787 \\
\hline Bear & 160 & 258.10 & 0.11020 & 292 & 30 & & 7 & & & 326.10 & .1219 & 734 & 35 & 11310 & 17.73 & 0.787 \\
\hline Goat & 185 & 316.50 & 0.08989 & 680 & 30 & 3.71 & 7 & 3.71 & 25.97 & 400.00 & 1492 & 896 & 596 & 13780 & 17.73 & 0.787 \\
\hline Sheep & 225 & 366.10 & 0.07771 & 745 & 30 & 3.99 & 7 & 3.99 & 27.93 & 462.60 & 1726 & 1036 & 690 & 15910 & 17.73 & 0.787 \\
\hline Kundah & 250 & 394.40 & 0.07434 & - & 42 & 3.50 & 7 & 1.94 & 26.82 & 424.80 & 1282 & 1120 & 162 & 9002 & 21.42 & 0.646 \\
\hline Deer & 260 & 419.30 & 0.06786 & 806 & 30 & 4.27 & 7 & 4.27 & 29.89 & 529.40 & 1977 & 1188 & 789 & 18230 & 17.73 & 0.787 \\
\hline Zebra & 260 & 418.60 & 0.06800 & 795 & 54 & 3.18 & 7 & 3.18 & 28.62 & 484.50 & 1623 & 1185 & 438 & 13316 & 19.35 & 0.686 \\
\hline Elk & 300 & 465.70 & 0.06110 & 860 & 30 & 4.50 & 7 & 4.50 & 31.50 & 588.40 & 2196 & 1320 & 876 & 20240 & 17.73 & 0.787 \\
\hline Camel & 300 & 464.50 & 0.06125 & - & 54 & 3.35 & 7 & 3.35 & 30.15 & 537.70 & 1804 & 1318 & 486 & 14750 & 19.36 & 0.686 \\
\hline Moose & 325 & 515.70 & 0.05517 & 900 & 54 & 3.53 & 7 & 3.53 & 3177 & 597.11 & 2002 & 1463 & 539 & 16250 & 19.53 & 0.686 \\
\hline Sparrow & 20 & 33.16 & 0.85780 & - & 6 & 2.67 & 1 & 2.67 & 8.01 & 39.22 & 135 & 92 & 43 & 1208 & 18.99 & 0.809 \\
\hline Fox & 22 & 36.21 & 0.78570 & 165 & 6 & 2.79 & 1 & 2.79 & 9.37 & 42.92 & 149 & 101 & 48 & 1313 & 18.99 & 0.809 \\
\hline
\end{tabular}

